\title{
Hepatocellular carcinoma: current state and future horizons
}

In this special series of Chinese Clinical Oncology on Hepatocellular Carcinoma (HCC) we are pleased to present timely and concise reviews by international experts. Hepatocellular carcinoma is one of the most common cause of cancer related mortality globally and has a dismal survival. Successful management of HCC requires a multidisciplinary approach including care team members with expertise in diagnostic techniques, management of viral hepatitis, surgical treatment modalities, liver transplantation, innovative ways to deliver radiation therapy, liver-directed therapy approaches, and finally cutting-edge systemic therapy modalities. In this special series, international experts provide an in-depth review of all the aforementioned topics. Despite nearly a decade of negative studies after approval of sorafenib, several new systemic therapy options have emerged in advanced HCC. The clinical trials which led to approval of several recently approved targeted therapy and immunotherapy agents are summarized. Potential systemic therapy options on the horizon and ongoing critical clinical trials are eloquently reviewed here. We hope that this in-depth review of the literature will be instrumental for guiding the multidisciplinary care of patients with hepatocellular carcinoma.

We sincerely thank the authors for their excellent contributions. We also would like to thank the editorial team for their assistance and opportunity to be Guest Editors for this special series on HCC.

\section{Acknowledgments}

Funding: None.

\section{Footnote}

Provenance and Peer Review: This article was commissioned by the editorial office, Chinese Clinical Oncology, for the series "Hepatocellular Carcinoma". The article did not undergo external peer review.

Conflicts of Interest: Both authors have completed the ICMJE uniform disclosure form (available at http://dx.doi.org/10.21037/cco2020-hc-11). The series "Hepatocellular Carcinoma" was commissioned by the editorial office without any funding or sponsorship. Drs. MA and SKM served as the unpaid Guest Editors of the series. Dr. MA reports others from Eisai, Ipsen, GSK, Exelixis, QED, outside the submitted work; Research: Tesaro (Inst), RedHill Biopharma Limited (Inst), Polaris (Inst), Bristol-Myers Squibb-Ono Pharmaceutical (Inst), Xencor (Inst), Merck Sharp \& Dohme (Inst), Eisai (Inst); Consulting or advisory role: Eisai, Ipsen, GSK, Exelixis, QED. The authors have no other conflicts of interest to declare.

Ethical Statement: The authors are accountable for all aspects of the work in ensuring that questions related to the accuracy or integrity of any part of the work are appropriately investigated and resolved.

Open Access Statement: This is an Open Access article distributed in accordance with the Creative Commons AttributionNonCommercial-NoDerivs 4.0 International License (CC BY-NC-ND 4.0), which permits the non-commercial replication and distribution of the article with the strict proviso that no changes or edits are made and the original work is properly cited (including links to both the formal publication through the relevant DOI and the license). See: https://creativecommons.org/licenses/by-nc$\mathrm{nd} / 4.0 \%$. 


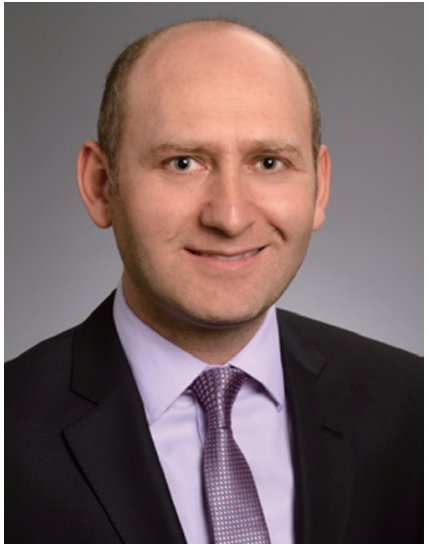

Mehmet Akce

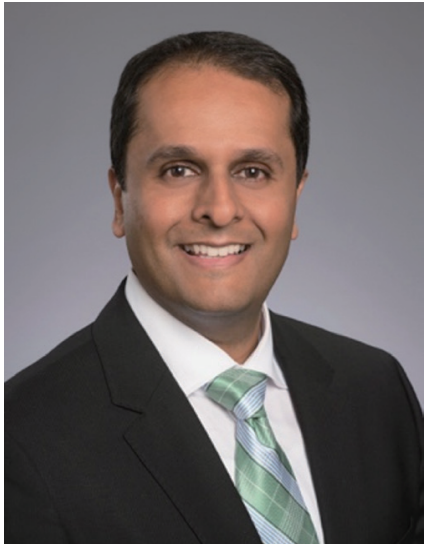

Shishir K. Maithel

Mehmet Akce, MD

Assistant Professor of Hematology and Medical Oncology, Winship Cancer Institute of Emory University, Atlanta, GA, USA.

(Email: Mehmet.akce@emory.edu)

Shishir K. Maithel, MD, FACS

Professor of Surgery,

Winship Cancer Institute, Division of Surgical Oncology, Department of Surgery, Emory University, Atlanta, GA, USA.

(Email: smaithe@emory.edu)

Submitted Nov 18, 2020. Accepted for publication Dec 20, 2020. doi: $10.21037 / \mathrm{cco}-2020-\mathrm{hc}-11$

View this article at: http://dx.doi.org/10.21037/cco-2020-hc-11

Cite this article as: Akce M, Maithel SK. Hepatocellular carcinoma: current state and future horizons. Chin Clin Oncol 2021;10(1):1. doi: 10.21037/cco-2020-hc-11 